Arnelle Y. Quiambao, MD

Flordelina E. Pio-Gulapan, MD

Department of Otolaryngology Head and Neck Surgery Far Eastern University - Dr. Nicanor Reyes

Medical Foundation Medical Center
Correspondence: Arnelle Y. Quiambao, MD Department of Otolaryngology Head Neck Surgery FEU- NRMF Medical Center

Regalado Ave. corner Dahlia St. West Fairview,

Quezon City 1118

Philippines

Telefax: (632) 9390470

E-mail: drayq2002@yahoo.com

Reprints will not be available from the author.

No funding support was received for this study. The authors signed a disclosure that they have no proprietary or financial interest with any organization that may have a direct interest in the subject matter of this manuscript, or in any product used or cited in this study.

Presented at Descriptive Research Contest ( $1^{\text {st }}$ Place) Philippine Society of Otolaryngology Head and Neck Surgery $51^{\text {st }}$ Annual Convention, Sofitel Philippine Plaza, Manila. December 1, 2007

North East Manila ENT- HNS Training Consortium Annual

Research Contest (3 $3^{\text {rd }}$ Place). September 2007.

\section{Competency in End-of-Life Care among ENT-HNS Consultants and Residents: A Multi-Center Study}

\begin{abstract} life care education

\section{Methods:}

Design: Cross- sectional survey

Setting: Five tertiary hospitals in Metro Manila

Subjects: 52 ENT-HNS consultants and residents
\end{abstract}

Objective: To determine the competency in End-of-Life Care of Ear, Nose, Throat - Head and Neck Surgery (ENT-HNS) consultants and residents using the domains of knowledge, skills and attitudes as measures of competency and to identify opportunities for improvement in end of

Results: The majority of the respondents scored low across the knowledge, attitude and skills domains. Majority the respondents (67\%) were low in the knowledge domain. More than half of the respondents (58\%) demonstrated negative attitudes towards end-of-life care while majority of the respondents (56\%) had low skills scores. Similarly, more than half $(67 \%)$ of the respondents showed low over-all competence in end-of-life care.

Conclusion: The majority of the respondents scored low across all three domains that were used to measure the competency in end of life care. These findings may suggest a need to strengthen the ENT- HNS practitioners' education in end-of-life care.

Key words: end-of-life care, palliative care, terminal care

There are $\mathbf{5 6}$ million deaths per year in the world, $85 \%$ of which are in developing countries. One can assume that each death also affects five other people in terms of informal care-giving and grieving relatives and friends- a very modest estimate, particularly in the developing world. The total number of people therefore, affected each year in the world by end-of-life care is about 300 million people, or about $5 \%$ of the world population. ${ }^{1}$

(C) Philippine Society of Otolaryngology - Head and Neck Surgery, Inc. 


\section{ORIGINAL ARTICLES}

As dying patients confront complex and unique challenges that threaten their physical, emotional and spiritual integrity, clinicians are recognizing the difficulties that arise when caring for the dying patient and their families. In addition to managing pain and multiple physical sources of distress, excellence in end-of-life care requires competencies in recognizing and treating psychological and physical distress; responding appropriately to intense emotions of patients and their families; understanding patients' and families' perspectives on care; recognizing and communicating imminence of death; facilitating difficult decision-making; and managing one's own sense of discomfort, uncertainty or loss.

Any effort to understand or improve quality end-of-life care must be sensitive to cultural considerations. ${ }^{1}$ It is known that attitudes toward end-of-life care are relative to particular cultures, societies and times. ${ }^{2}$ Furthermore, even within the same culture, health care providers and patients may disagree on the principles which are influencing the decision-making process. Simply applying Western perspectives on end-of-life-care to our country are unrealistic and bound to fail.

Physician competence in end-of-life care requires skill in communication, decision making and building relationships. Physician ability in this area correlates directly with patients feeling satisfied with their medical care and adhering to medical advice. ${ }^{3}$ It may also enhance physicians' own experiences of providing care. Yet these skills were barely taught to the majority of physicians during their training.

Over the past years, end-of-life care has become an essential aspect of medical care in many parts of the world. There is a deeper recognition of the need to improve in end-of-life care. However, the issue of death and dying in the context of patient care, requisite knowledge and clinical competence has received little attention in the environment of medical education and residency training. Despite this recent interest and the inevitability of death, several studies have documented that end-of-life care is inadequately taught during medical school and residency training, ${ }^{4}$ even in developed countries like the United States. In 1995, only $26 \%$ of residency programs in the United States offered courses on care at the end of life as part of the curriculum, and $15 \%$ of programs offered no formal training. ${ }^{5}$ Another report from the Institute of Medicine (IOM) of the National Academy of Sciences in 1997 identified large gaps in knowledge of care at end of life which demanded attention from biochemical, social science and health service researches. The report, entitled Approaching Death, clearly indicated health care professionals' lack of education about endof-life care as a major barrier to improvement of services. ${ }^{6}$

An ideal vision in end-of-life is one in which people die peacefully and comfortably at home, surrounded by supportive family and friends. However, many individuals die in hospitals in the care of their physicians. Health care institutions are now examining ways to improve physician competence in the delivery of end-of-life care. Experts have suggested that influencing physician's knowledge and attitudes concerning endof-life care can influence subsequent skills. Furthermore, studies have shown that increasing the knowledge and skills in end-of-life care will enhance the level of competence of physicians in this area.? (Figure 1).

\section{General Objective:}

\section{OBJECTIVES}

To determine the competency in end-of-life care among ENT-HNS consultants and residents in five tertiary hospitals in Metro Manila.

\section{Specific Objectives:}

\section{Figure 1. Competency in end-of-life care lies primarily in adequate knowledge and skills as well as positive attitudes towards end-of-life care.}

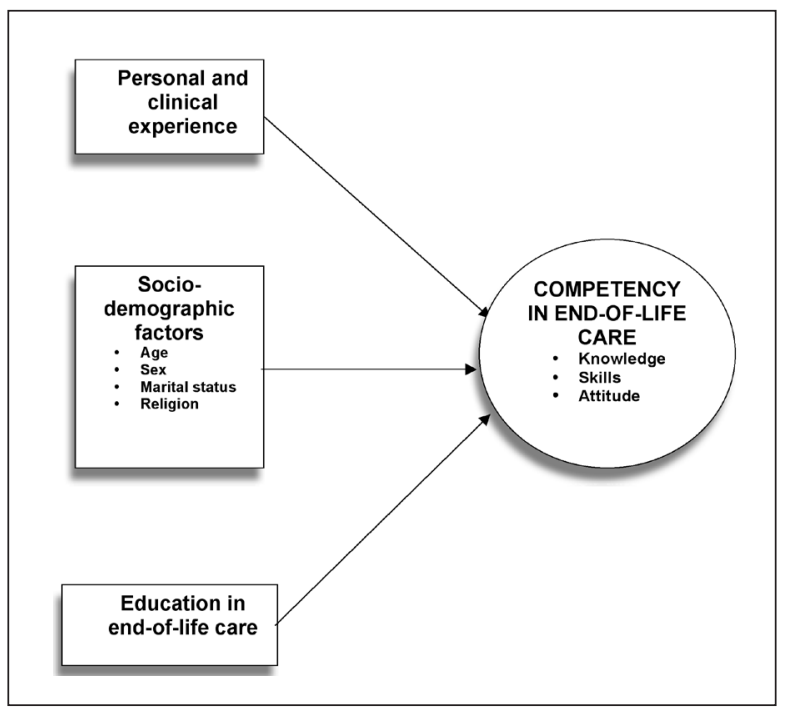

1. To determine the competency in end-of-life care of ENT-HNS consultants and residents using the following domains:

a. Knowledge
b. Skills

c. Attitude

2. To identify opportunities for improvement in end-of-life care education

\section{METHODOLOGY}

A cross- sectional study was conducted in the Departments of ENT- HNS in five tertiary hospitals in Metro Manila, namely: Far Eastern University - Dr. Nicanor Reyes Medical Foundation Medical Center, Veterans Memorial Medical Center, Manila Central University Hospital, Quirino Memorial Medical Center and Armed Forces of the Philippines Medical Center.

Consultants and residents who agreed to participate in the study were included. The required sample size was based on the following computation for social science studies:

1. For previously validated questions (Part Il: $q 1, q 2, q 3, q 4, q 5, q 7, q 8, q 9$, q10,q12; Part III:q1, q2, q3, q4, q5, q6,q7, q9, q10; Part IV:q1a, q1b, q1c, q1d, $q 1 e, q 2 a, q 2 b, q 2 c)$ : Total items 27)

Formula: 1 question item: 1 respondent

Therefore, 27 respondents

2. For unvalidated questions (Part II: q6, q11, q13; Part III: q8; Part IV: $q 3 a, q 3 b, q 3 c$ : Total items 7) 
Formula: Number of items $x 3=$ Number of respondents

Therefore, 21 respondents

Hence, the required sample size was forty eight.

\section{B. Survey Instrument:}

A self- administered questionnaire was developed based on the three domains (knowledge, attitudes and skills) that can measure the competency in end-of-life care. Majority of the questions covering the three domains were obtained from previously-validated questionnaires (Wenger, 1998; Bui, 2002; Stoeckie, 1998; Yacht, 2007; Ganzini, 2001; Appendix 1). The rest of the questions were based on in-depth review of current principles in end-of-life care (Von Gunten, 2000; Ferris, 2000; Yacht, 2007; Appendix 1). The questionnaire was divided into four sections, as detailed in Table 1 .

Questions on knowledge and skills domains covered the following end-of-life care core competencies:

1. Advance care planning

2. Communicating with the dying patient and the family

3. Symptom and pain assessment and management

Questions on the attitude domain covered the following areas:

1. Religion and spirituality

2. Beliefs

3. Personal comfort with the care of the dying

4. Desire

5. Motivation

The knowledge subscale required the respondent to choose an answer from a 3-point scale ranging from "disagree" to "agree". Each statement was designed to have one ethically-appropriate response grounded in authoritative sources from the clinical ethics literature. Scores from each question were added to comprise a knowledge score. The knowledge score was categorized low or high and defined as follows:

Low: $\leq 31$ of score

High: $>31$ of score

For the attitude subscale, respondents answered questions on dual 5- point Likert scales ranging from "strongly disagree" to "strongly agree". Each statement was assigned as either positive or negative attitude. Three of the ten attitudinal items were negative attitudes. Scores were added to comprise an attitudinal score. The attitudinal score was categorized as low or high and defined as follows:

Low: $\leq 33$ of score

High: $>33$ of score

For the skills subscale, respondents were given brief clinical scenarios presenting with problems that required a response from a physician. The respondents were required to choose an answer from a 3-point scale ranging from "disagree" to "agree". Scores were added to comprise a skills score. The skills score was categorized as low or high and defined as follows:

Low: $\leq 23$ of score

High: $>23$ of score
A composite competency score for the full sets of questions was calculated by combining the scores for the three subscales. Competency score was dichotomized into its mean, categorized as low or high and defined as follows:

Low: $\leq 88$ of score

High: $>88$ of score

\section{Validation of Instrument:}

A 34-item self-administered questionnaire in English language was pre- tested among 20 physicians. Measures of central tendency (mean), standard deviation, frequencies and percentages were derived for each item. Data analysis involved frequency endorsements, inter- item correlation, inter-total correlation and Cronbach's coefficient alpha. A Cronbach's alpha of 0.8 is desirable but 0.6 is acceptable. For the pretesting of our questionnaire, the Cronbach's alpha computed was 0.7 (Appendix 3).

\section{Data Collection and Analysis:}

All data gathered were encoded using Microsoft Excel (Microsoft Corporation, Redmond, WA, USA) and analyzed using Statistical Package for the Social Sciences (SPSS) version 10.0 for Windows software (SPSS Inc., Chicago, III, USA). Data collected were treated using descriptive statistics. Measures of central tendency (mean), standard deviation, frequencies and percentages were then derived for each item.

\section{LIMITATIONS OF THE STUDY}

There are a number of limitations in this study. First, it was limited to five ENT- HNS training institutions, hence, the results of the study might not be generalizable to other ENT- HNS physicians and specialties. Second, the subjects may have different definitions or interpretations of "formal education in end-of-life care" since it was not qualified in the questionnaire. Although there was verbal explanation of its meaning during the actual survey, there might still have been some degree of confusion as to its meaning among the subjects. Lastly, the subspecialty practice of the consultants surveyed was not specified. This might have resulted in possible bias from the proportion of the consultants who are specifically engaged in oncology practice.

\section{DEFINITION OF TERMS}

1. End-of-life care - refers to the medical and psychosocial care given in the advanced or terminal stages of illness. An approach that improves the quality of life of patients and their families facing the problems associated with life- threatening illnesses, through the prevention and relief of suffering.

2. Knowledge - defined as the state of cognition or understanding principles applied to end-of-life care.

3. Skills- defined as proficiency or facility that is acquired or developed through training or experience in end-of-life care.

4. Attitudes- defined as psychological tendency that is expressed by evaluating a particular entity with some degree of favor or disfavor.

5. Competency - defined as a state of being qualified to handle end of life care issues; measured by knowledge, skills and attitudes towards end-of-life care. 


\section{RESULTS}

A total of 52 ENT consultants and residents were included in the study. The mean age was $35.06+/-6.56$. The majority of respondents were male, constituting $63 \%$ of the total subjects. A little more than half $(52 \%)$, were single while $48 \%$ were married. Most of the respondents (90\%) were Catholics while the rest were from other religions. Consultants comprised $56 \%$ of the subjects while residents constituted $44 \%$. Almost half ( $44 \%$ ) had education in end-of-life care during medical school, while $92 \%$ had personal experiences with the death of a family member or a close friend. Most of the respondents, $79 \%$, had experience in caring for the dying. Of these, $29 \%$ had 1 year of clinical experience, $24 \%$ had 2-3 years, and another $24 \%$ had $4-5$ years experience while the remaining $22 \%$ had $>5$ years of clinical experience in the care of the dying patient (Table 3).

Table 4 (Appendix 2 A) shows that majority of respondents (67\%) scored low in the knowledge domain, with most of the consultants $(62 \%)$ and residents (74\%) obtaining scores below the mean $(<31)$.

Table 5 (Appendix 2 B) shows that more than half of the respondents (58\%) demonstrated negative attitudes towards end of life care, as shown by their low attitudinal score. A greater number of both consultants $(55 \%)$ and residents $(61 \%)$ obtained attitudinal scores below the mean $(<33)$.

Table 6 (Appendix 2 C) shows that more consultants (62\%) obtained low scores on skills than residents (48\%). However, when combined, majority of the respondents (56\%) had low skills scores.

The composite competency score of the respondents revealed that the majority (67\%) show low competence in end-of-life care. $74 \%$ of residents and $62 \%$ of the consultants obtained scores below the mean (Table 7).

\section{DISCUSSION}

The issue of death and dying in the context of patient care, requisite knowledge and clinical competence has become very important. However, it has received limited interest, especially in developing

\section{Table 1. Survey Questionnaire}

\begin{tabular}{c|c|c} 
Section & Category & Number of Items \\
\hline I & Socio- demographic variables & 8 items \\
\hline II & Knowledge about end-of-life care & 13 items \\
\hline III & Attitudes regarding end-of-life & 10 items \\
\hline IV & Skills on end-of-life care & 11 items
\end{tabular}

Table 2. Descriptives of Scores on the Different Areas of Competency in End-of-Life Care

\begin{tabular}{l|c|c}
\multicolumn{1}{c|}{ Areas } & Highest Possible Score & Mean \\
Knowledge & 39 & $31.03(26-37)$ \\
\hline Attitude & 50 & $33.65(25-43)$ \\
\hline Skills & 33 & $23.54(17-33)$ \\
\hline Over-All & 122 & $88.23(73-112)$ \\
\hline
\end{tabular}

Table 3. Demographic Characteristics of Respondents

\begin{tabular}{|c|c|}
\hline $\begin{array}{l}\text { Profiles } \\
\mathrm{N}=52\end{array}$ & $\begin{array}{l}\text { Total } \\
\text { n (\%) }\end{array}$ \\
\hline Age (in years) & Mean $+/$-SD $=35.06+/-6.56$ \\
\hline $\begin{array}{l}\text { Sex } \\
\text { Male } \\
\text { Female } \\
M: F=2: 1\end{array}$ & $\begin{array}{l}33(63.5) \\
19(36.5)\end{array}$ \\
\hline $\begin{array}{l}\text { Civil Status } \\
\text { Single } \\
\text { Married } \\
\text { S:M=1:1 }\end{array}$ & $\begin{array}{l}27(51.9) \\
25(48.1)\end{array}$ \\
\hline $\begin{array}{l}\frac{\text { Religion }}{\text { Catholic }} \\
\text { INC } \\
\text { Protestant } \\
\text { Others }\end{array}$ & $\begin{array}{c}47(90.4) \\
1(1.9) \\
2(3.8) \\
2(3.8)\end{array}$ \\
\hline $\begin{array}{l}\text { Category } \\
\text { Consultant } \\
\text { Resident }\end{array}$ & $\begin{array}{l}29(55.8) \\
23(44.2) \\
\end{array}$ \\
\hline $\begin{array}{l}\text { Formal Training/Education } \\
\text { None } \\
\text { Residency } \\
\text { Medical School } \\
\text { Self-Educated }\end{array}$ & $\begin{array}{c}13(25.0) \\
15(28.8) \\
23(44.2) \\
1(1.9) \\
\end{array}$ \\
\hline $\begin{array}{l}\text { Personal Experience with death of family } \\
\text { member or close friend } \\
\text { Yes } \\
\text { No }\end{array}$ & $\begin{array}{c}48(92.3) \\
4(7.7)\end{array}$ \\
\hline $\begin{array}{l}\text { Clinical experience in the care of dying } \\
\text { patients } \\
\text { Yes } \\
\text { No }\end{array}$ & $\begin{array}{l}41(78.8) \\
11(21.2)\end{array}$ \\
\hline $\begin{array}{l}\text { Years of clinical experience in the care of } \\
\frac{\text { dying patients }}{1} \\
2 \\
3 \\
4\end{array}$ & $\begin{array}{l}(n=41) \\
12(29.3) \\
10(24.4) \\
10(24.4) \\
9(21.9)\end{array}$ \\
\hline
\end{tabular}

Table 4. Distribution of Respondents According to Category and Knowledge Scores

\begin{tabular}{l|c|c|c|}
\multicolumn{1}{c|}{ Category } & \multicolumn{2}{|c|}{ Knowledge Score } & Total \\
& High (>31) & Low(</=31) & \\
\hline Consultant & $11(38.0 \%)$ & $18(62.0 \%)$ & 29 \\
\hline Resident & $6(26.0 \%)$ & $17(74.0 \%)$ & 23 \\
\hline Total & $17(32.7 \%)$ & $35(67.3 \%)$ & 52 \\
\hline
\end{tabular}

Table 5. Distribution of Respondents According to Category and Attitude Scores

\begin{tabular}{l|c|c|c}
\multicolumn{1}{c|}{ Category } & \multicolumn{2}{|c|}{ Attitude Score } & Total \\
& High $(>\mathbf{3 3})(\mathbf{n = 2 2})$ & Low $(</=\mathbf{3 3 )} \mathbf{( \mathbf { n } = \mathbf { 3 0 } )}$ & \\
\hline Consultant & $13(45.0 \%)$ & $18(62.0 \%)$ & $16(55.0 \%)$ \\
\hline Resident & $9(39.0 \%)$ & $17(74.0 \%)$ & $14(61.0 \%)$ \\
\hline Total & $22(42.3 \%)$ & $35(67.3 \%)$ & $30(57.7 \%)$ \\
\hline
\end{tabular}




\section{ORIGINAL ARTICLES}

Table 6. Distribution of Respondents According to Category and Skills Scores

\begin{tabular}{l|c|c|c}
\multicolumn{1}{c|}{ Category } & \multicolumn{2}{|c|}{ Skills Score } & Total \\
& High $(>\mathbf{2 3})(\mathbf{n = 2 3 )}$ & Low(</=23)(n=29) & \\
\hline Consultant & $11(38.0 \%)$ & $18(62.0 \%)$ & 29 \\
\hline Resident & $12(52.0 \%)$ & $11(48.0 \%)$ & 23 \\
\hline Total & $23(44.2 \%)$ & $29(55.8 \%)$ & 52 \\
\hline
\end{tabular}

Table 7. Distribution of Respondents According to Category and Over-All Competency Score

\begin{tabular}{l|c|c|c}
\multicolumn{1}{c|}{ Category } & \multicolumn{2}{|c|}{ Over-all Score } & Total \\
& High (>88) & Low(</=88) & \\
\hline Consultant & $11(38.0 \%)$ & $11(62.0 \%)$ & 29 \\
\hline Resident & $6(26.0 \%)$ & $17(74.0 \%)$ & 23 \\
\hline Total & $17(32.7 \%)$ & $35(67.3 \%)$ & 52 \\
\hline
\end{tabular}

countries like ours. Thus, little is known about the status of end-of-life care in the local setting. The problem of quality end-of-life care is the lack of information. It is difficult to know how to improve quality end-oflife care without any understanding of what the current quality is, what determines it, and how improvement can be measured. The results of this survey provide initial information about end-of-life care among ENT- HNS consultants and residents in the five training institutions identified.

Majority of the respondents (67\%) obtained a low score in the knowledge domain. The results were similar for both consultants and residents. This demonstrated their lack of understanding of the different end-of-life care core competencies, such as advance care planning, communicating with dying patients and their families and symptom and pain assessment and management (Appendix 2 A). For example, there was confusion with the meaning of the question regarding "do not resuscitate" (D-N-R) orders. Ninety two percent of the respondents agreed that it precludes the use of cardio-pulmonary resuscitation. However, $75 \%$ said that it only instructs the physician to provide comfort measures. A D-N-R order only directs the physician not to resuscitate a patient, but has no effect on other treatment modalities. The misconception that it has a much broader meaning than intended leads physicians to underuse such orders. Many, too, held misconceptions regarding end of life decision- making. Many agree that decisions on the care of a terminally- ill patient are established by the best interest decision made by the family and the physician (78\%) and decision- making on the care of the dying patient is based on reliance on a family member's interpretation of patient's wishes $(60 \%)$. These choices revealed that respondents did not universally recognize that a patient's preference concerning end-of-life care should be respected, even when the strategy would permit death.

The result in the knowledge domain was reflected in the respondents'score in the skills domain. While more residents obtained higher skills scores than consultants, still more than half or $56 \%$ of the total respondents obtained low skills scores. This shows that ability to have adequate end of life care skills is developed from a comprehensive knowledge base of end-of-life care core competencies.

Similarly, majority of the respondents (58\%) had negative attitudes towards end-of-life care, with $55 \%$ of consultants and $61 \%$ of residents obtaining low attitudinal scores (Appendix 2 B). Although training and exposure in the care of the terminally-ill was endorsed by more than half of the respondents $(52 \%)$, there were contrasting results with regard to the respondents' motivation to care for dying patients. Only $39 \%$ of the respondents found caring for dying patients rewarding or fulfilling. It was of concern also that the same number of respondents (38\%) derived greater satisfaction from caring for patients who are expected to improve than with patients who are likely to die.

The ability to give optimum care for the terminally- ill can be deduced from the respondents' scores. Over-all competency scores showed that only $33 \%$ of the respondents were shown to be competent in handling end-of-life care issues, with majority of consultants (62\%) and residents ( $74 \%$ ) obtaining low scores on over-all competency. The finding that majority of the ENT- HNS practitioners showed low over-all competency in end-of-life care may not come as a surprise for some who would argue that ENT specialists encounter death and dying patients less commonly than their colleagues in other disciplines. In the field of ENT, end-of-life care situations may not occur regularly, and this may have probable implications in the way ENT clinicians view and handle end-of-life care situations. A study by Teneza et al found that physicians with more years of clinical experience in the care of dying patients had appropriate practice and positive attitudes in end of life care. "1 Other factors to be considered are barriers such as lack of access to well-trained palliative care physicians who can serve as leaders in clinical care and education, as well as access to end-of-life care services in the respondents' hospitals of practice. Compounding this problem is the lack of information about good end-of-life care in mainstream textbooks which physicians turn to for information. A study by Wu et al in 2006 about end-of-life content in geriatric textbooks concluded that most geriatric textbooks lack good coverage on end-of-life care ${ }^{12}$. As a result of these different factors, physicians often learn on their own to contend with problems of death. Be that as it may, these facts should not negate the need for us to undertake steps towards delivering quality end-of-life care. Moreover, this finding should prompt us that the model and concept of end-of-life care should be introduced in our training and practice of ENT.

Indeed, the lack of knowledge related to the end-of-life experience represents a health information deficit. It is remarkable that such a significant element of health care delivery is so poorly understood. It is hoped that the results of this study will encourage our colleagues to take a look into the importance of delivering quality care to our dying patients and their families. In our country where healthcare resources, both public and private, are geared towards prevention of death, we believe that efforts to evaluate and improve patient's experiences at the end of life must also be addressed.

Caring for patients at the end of life is one of the greatest challenges 
most clinicians ever face, yet it can be one of the most appreciated and personally- rewarding experiences. Listening to the rich and varied perspectives of our dying patients and their families will help meet his challenge.

Dying is indeed inevitable, and while there is no way out, there is a way through.

Our findings may suggest a need to strengthen the ENT- HNS practitioners' education in end-of-life care. Greater emphasis should be placed on training in the care of dying patients by providing opportunities for learning such as symposia, didactic lectures or seminars. The improvement in the competency in end-of-life care will translate into better care and improved quality of life of dying patients.

\section{APPENDIX 1}

Good day! We are conducting a survey to determine the competency in end-of-life care among ENT-HNS consultants and residents. Please fill up the questionnaire as completely as you can. This survey is completely voluntary and will take only a few minutes of your time. Your identity and answers will be kept confidential. Thank you.

AYQ/FEP

\section{COMPETENCY IN END-OF-LIFE CARE AMONG ENT- HNS CONSULTANTS AND RESIDENTS- A MULTI- CENTER STUDY \\ ID Number:}

\section{PARTI DEMOGRAPHIC PROFILE}

1. Initials:

2. Age (years):

3. Gender: $\square$ Male $\square$ Female

4. Civil Status:

$\square$ Single a Married a Separated a Widow/er

\section{Religion/Religious Affiliation:}

$\square$ Catholic $\square$ Muslim $\square$ INC $\square$ Protestant $\square$ Others:

\section{Category:}

$\square$ Consultant $\square$ Resident

\section{Formal training/education on care of the dying?}

$\square$ Residency a Self-educated a Medical school a None

8. Personal experience with the death of a family member or a close friend?

$\square$ Yes a No

\section{Clinical experience in the care of the dying patient/s?}

$\square$ Yes $\square$ No

If yes, for how many years?

$$
\text { ] 0-1 } \begin{array}{llll}
2-3 & \square & 4-5 & \square>5
\end{array}
$$

\section{Questionnaire adapted and revised from:}

1. Wenger NS, Lieberman JR. An Assessment of Orthopedic Surgeons' Knowledge of Medical Ethics. Journal of Bone and Joint Surgery, February 1998; 80, 2: 198-206; ProQuest Medical Library.

\section{PART II}

Direction: Please read each statement about end-of-life care carefully. Please check or encircle the number that you consider as most appropriate to each statement.

\begin{tabular}{|c|c|c|c|}
\hline & $\begin{array}{l}\text { DIS- } \\
\text { AGREE }\end{array}$ & $\begin{array}{l}\text { UN- } \\
\text { SURE }\end{array}$ & AGREE \\
\hline $\begin{array}{l}\text { 1. D-N-R (Do-Not Resuscitate) order means withholding cardio- } \\
\text { pulmonary resuscitation }{ }^{1}\end{array}$ & 1 & 2 & 3 \\
\hline $\begin{array}{l}\text { 2. A D-N-R order instructs the physician to provide comfort measures } \\
\text { only }{ }^{1}\end{array}$ & 1 & 2 & 3 \\
\hline $\begin{array}{l}\text { 3. Advance Directives designates an individual to make decisions for the } \\
\text { patients if the patient is unable to do } \mathrm{so}^{1}\end{array}$ & 1 & 2 & 3 \\
\hline $\begin{array}{l}\text { 4. Decisions on the care of a terminally- ill patient is established by the } \\
\text { best interest decision made by the family and the physician' }\end{array}$ & 1 & 2 & 3 \\
\hline $\begin{array}{l}\text { 5. Decision- making on the care of the dying patient is based on reliance } \\
\text { on a family member's interpretation of patient's wishes' }\end{array}$ & 1 & 2 & 3 \\
\hline $\begin{array}{l}\text { 6. Delivering information to patients and their families are carried out in a } \\
\text { sensitive but straight- forward manner }{ }^{2}\end{array}$ & 1 & 2 & 3 \\
\hline 7. Patients should be encouraged to talk about their impending death ${ }^{3}$ & 1 & 2 & 3 \\
\hline $\begin{array}{l}\text { 8. End of life care discussions facilitate physician and family agreements } \\
\text { on management }{ }^{4}\end{array}$ & 1 & 2 & 3 \\
\hline $\begin{array}{l}\text { 9. Open communication bridges the gap between patient's perception of } \\
\text { his situation and the reality }{ }^{2}\end{array}$ & 1 & 2 & 3 \\
\hline $\begin{array}{l}\text { 10. Withholding negative information to a patient will result to a better } \\
\text { treatment outcome }\end{array}$ & 1 & 2 & 3 \\
\hline $\begin{array}{l}\text { 11. An increasing need for more analgesic by a terminally-ill patient } \\
\text { reflects the progression of symptoms and underlying disease }{ }^{5}\end{array}$ & 1 & 2 & 3 \\
\hline $\begin{array}{l}\text { 12. It is the role of the physicians to address the psychosocial issues of } \\
\text { dying patients }\end{array}$ & 1 & 2 & 3 \\
\hline $\begin{array}{l}\text { 13. Higher doses of narcotics will shorten life or depress respiration in } \\
\text { dying patients }\end{array}$ & 1 & 2 & 3 \\
\hline
\end{tabular}

2. Von Gunten C., Ferris F., Emanuel L. Ensuring competency in endof-life care. JAMA, 2000; 284:23.

3. Bui E, Huggins MA. The Knowledge, Attitudes and Practices of Physicians in End-of-Life Care. University of Toronto Medical Journal, March 2002; 79(2):88-93.

4. Stoeckie ML, Doorley JE, MacArdle RM. Identifying compliance with end-of-life care decision protocols. Dimensions of Critical Care Nursing, Nov/Dec 1998; 17, 6:314-320; ProQuest Medical Library.

5. Ferris FD, von Gunten CF, Emanuel LL. Ensuring competency in endof-life care: controlling symptoms. BMC Palliative Care, July 2002

6. Yacht, AC, Suglia, SF, Orlander, JD. Evaluating an end-of-life curriculum in a medical residency program. American Journal of Hospice and Palliative Medicine. January2007; 23 (6): 439-446.

7. Ganzini L, Nelson HD, Lee MA, Kraemer DF, Schmidt TA, Delorit MA. Oregon Physicians' Attitudes About and Experiences with End-of-Life Care since Passage of the Oregon Death with Dignity Act. JAMA, May 2001; 285(18):2363-2369.

8. Burge F., Mclntyre P., Kaukman, D., Cummings, I. Family medicine residents' knowledge and attitudes about end-of-life care. Journal of Palliative Care; Autumn 2000; 16, 3; ProQuest Medical Library. 
PART III

Direction: Please read each statement about end-of-life care carefully. Please check or encircle the number that you consider as most appropriate to each statement.

\begin{tabular}{|l|c|c|c|c|c|}
\hline & $\begin{array}{l}\text { STRONGLY } \\
\text { DISAGREE }\end{array}$ & $\begin{array}{c}\text { DIS- } \\
\text { AGREE }\end{array}$ & UNSURE & AGREE & $\begin{array}{c}\text { STRONGLY } \\
\text { AGREE }\end{array}$ \\
\hline $\begin{array}{l}\text { 1.Faith plays an important role in the ability of } \\
\text { patients to deal with medical illness and dying }\end{array}$ & 1 & 2 & 3 & 4 & 5 \\
\hline $\begin{array}{l}\text { 2. Physician- patient interactions would be } \\
\text { strengthened if physicians regularly discuss their } \\
\text { patient's spirituality or religion with them }\end{array}$ & 1 & 2 & 3 & 4 & 5 \\
\hline $\begin{array}{l}\text { 3.Physicians should frequently initiate discussions } \\
\text { about spiritual /religious matters with their } \\
\text { patient during end-of-life care }\end{array}$ & 1 & 2 & 3 & 4 & 5 \\
\hline $\begin{array}{l}\text { 4. Treating a dying patient is one of the most } \\
\text { unpleasant aspects of being a physician }\end{array}$ & 1 & 2 & 3 & 4 & 5 \\
\hline $\begin{array}{l}\text { 5. If given a choice, I prefer to avoid contact with } \\
\text { dying people }\end{array}$ & 1 & 2 & 3 & 4 & 5 \\
\hline $\begin{array}{l}\text { 6. The physician should be comfortable providing } \\
\text { life-prolonging measures if the patient and family } \\
\text { request them }\end{array}$ & 1 & 2 & 3 & 4 & 5 \\
\hline $\begin{array}{l}\text { 7. The physician should be comfortable } \\
\text { withdrawing life- prolonging measures if the } \\
\text { patient and family request them }\end{array}$ & 1 & 2 & 3 & 4 & 5 \\
\hline $\begin{array}{l}\text { 8. Training and exposure in the care of the } \\
\text { terminally-ill should be mandatory to all } \\
\text { physicians }\end{array}$ & 1 & 2 & 3 & 4 & 5 \\
\hline $\begin{array}{l}\text { 9. It is more satisfying to work with patients who } \\
\text { are expected to improve than with patients who } \\
\text { are likely to die }\end{array}$ & 1 & 2 & 3 & 4 & 5 \\
\hline $\begin{array}{l}\text { 10. Caring for dying patients is rewarding or } \\
\text { fulfilling }\end{array}$ & 1 & 2 & 3 & 4 & 5 \\
\hline
\end{tabular}

\section{PARTIV}

Direction: Please read each brief clinical scenarios carefully. Please check or encircle the number that you consider as most appropriate to each statement.

\section{CASE 1}

A 50-year-old man was severely injured in a boating accident. He was submerged for more than 5 minutes when rescuers arrived. After a successful resuscitation and stabilization, he was taken to the OR for treatment of multiple facial injuries. Post- operatively, he was managed for anoxic brain damage by the neurology department but the family turns to you for decision. After a week of observation, the patient remains in deep coma and it is clear that he will never recover mental function, although his lungs are improving to the point he might be weaned from the ventilator and all other organ function is good. All members of the man's family agree that he would never want to live in this state and that he should be allowed to die. What maneuvers are acceptable? ${ }^{1}$

\begin{tabular}{|l|c|c|c|}
\hline & $\begin{array}{c}\text { DIS- } \\
\text { AGREE }\end{array}$ & $\begin{array}{c}\text { UN- } \\
\text { SURE }\end{array}$ \\
\hline a. Write a Do-Not-Resuscitate order & 1 & 2 & 3 \\
\hline b. Remove the patient from ventilator & 1 & 2 & 3 \\
\hline c. Start morphine drip for the purpose of suppressing respiration & 1 & 2 & 3 \\
\hline d. Stop total parenteral nutrition & 1 & 2 & 3 \\
\hline e. Remove the patient out of the ICU & 1 & 2 & 3 \\
\hline
\end{tabular}

\section{CASE 2}

One day, you speak with a family that is distraught concerning the condition of their 65 -year-old mother who has been in the ICU for 4 weeks. An infection developed after an operation for laryngeal carcinoma. The patient became septic, went into atrial fibrillation and suffered a stroke. She is now unresponsive; is being ventilated and is receiving pressors, dialysis and antibiotics. The family explained that they are sad regarding the outcome but have accepted their mother's fate. They are most upset that she is kept alive because she had made them promise that she would never be kept alive on machines if she could not return to functional state: a conclusion that the neurologists came to with certainty 2 weeks ago. What should be done?

\begin{tabular}{|l|c|c|c|}
\hline & $\begin{array}{c}\text { DIS- } \\
\text { AGREE }\end{array}$ & $\begin{array}{c}\text { UN- } \\
\text { SURE }\end{array}$ & AGREE \\
\hline a. A psychologist or social worker should be called to help & 1 & 2 & 3 \\
\hline b. The patient should be made comfortable and be allowed to die & 1 & 2 & 3 \\
\hline c. The patient should be transferred to a long-term-care facility & 1 & 2 & 3 \\
\hline
\end{tabular}

\section{CASE 3}

Mrs. $X$ is a terminal cancer patient who has been complaining of escalating pain for the past 2 weeks. Despite receiving opioid analgesics, she is still in pain and is pleading for relief. She appears dyspneic and withdrawn, has poor eye contact and doesn't say much. What measures are appropriate?'

\begin{tabular}{|l|c|c|c|}
\hline & $\begin{array}{c}\text { DIS- } \\
\text { AGREE }\end{array}$ & $\begin{array}{c}\text { UN- } \\
\text { SURE }\end{array}$ & AGREE \\
\hline $\begin{array}{l}\text { a. Include non- pharmacologic interventions and interdisciplinary plan } \\
\text { that include other healthcare professionals in addition to pharmacologic } \\
\text { treatment }\end{array}$ & 1 & 2 & 3 \\
\hline $\begin{array}{l}\text { b. Refuse request to increase doses of pain medication because she is } \\
\text { showing signs of addiction }\end{array}$ & 1 & 2 & 3 \\
\hline $\begin{array}{l}\text { c. Sit down and engage her in conversation encouraging her to express } \\
\text { her feelings }\end{array}$ & 1 & 2 & 3 \\
\hline
\end{tabular}




\section{APPENDIX 2}

\section{2-A. Distribution of Respondents According to their Responses on the Different Knowledge Questions}

\begin{tabular}{|c|c|c|c|}
\hline & DIS-AGREE & UNSURE & AGREE \\
\hline $\begin{array}{l}\text { 1. D-N-R ( Do-Not-Resuscitate) order means withholding cardio- } \\
\text { pulmonary resuscitation }\end{array}$ & $\begin{array}{c}3 \\
(5.8 \%) \\
\end{array}$ & $\begin{array}{c}1 \\
(1.9 \%) \\
\end{array}$ & $\begin{array}{c}48 \\
(92.3 \%) \\
\end{array}$ \\
\hline $\begin{array}{l}\text { 2. A D-N-R order instructs the physician to provide comfort measures } \\
\text { only }\end{array}$ & $\begin{array}{c}8 \\
(15.4 \%) \\
\end{array}$ & $\begin{array}{c}5 \\
(9.6 \%) \\
\end{array}$ & $\begin{array}{c}39 \\
(75.0 \%)\end{array}$ \\
\hline $\begin{array}{l}\text { 3. Advance Directives designates an individual to make decisions for } \\
\text { the patients if the patient is unable to do so }\end{array}$ & $\begin{array}{c}2 \\
(3.8 \%) \\
\end{array}$ & $\begin{array}{c}14 \\
(26.9 \%) \\
\end{array}$ & $\begin{array}{c}36 \\
(69.2 \%) \\
\end{array}$ \\
\hline $\begin{array}{l}\text { 4. Decisions on the care of a terminally- ill patient is established by } \\
\text { the best interest decision made by the family and the physician }\end{array}$ & $\begin{array}{c}10 \\
(19.2 \%)\end{array}$ & $\begin{array}{c}2 \\
(3.8 \%) \\
\end{array}$ & $\begin{array}{c}40 \\
(76.9 \%)\end{array}$ \\
\hline $\begin{array}{l}\text { 5. Decision- making on the care of the dying patient is based on } \\
\text { reliance on a family member's interpretation of patient's wishes }\end{array}$ & $\begin{array}{c}14 \\
(26.9 \%)\end{array}$ & $\begin{array}{c}7 \\
(13.5 \%)\end{array}$ & $\begin{array}{c}31 \\
(59.6 \%)\end{array}$ \\
\hline $\begin{array}{l}\text { 6. Delivering information to patients and their families are carried out } \\
\text { in a sensitive but straight- forward manner }\end{array}$ & 0 & $\begin{array}{c}2 \\
(3.8 \%) \\
\end{array}$ & $\begin{array}{c}50 \\
(96.2 \%)\end{array}$ \\
\hline $\begin{array}{l}\text { 7. Patients should be encouraged to talk about their impending } \\
\text { death }\end{array}$ & $\begin{array}{c}4 \\
(7.7 \%) \\
\end{array}$ & $\begin{array}{c}4 \\
(7.7 \%) \\
\end{array}$ & $\begin{array}{c}44 \\
(84.6 \%) \\
\end{array}$ \\
\hline $\begin{array}{l}\text { 8. End of life care discussions facilitate physician and family } \\
\text { agreements on management }\end{array}$ & $\begin{array}{c}1 \\
(1.9 \%)\end{array}$ & $\begin{array}{c}5 \\
(9.6 \%)\end{array}$ & $\begin{array}{c}46 \\
(88.5 \%)\end{array}$ \\
\hline $\begin{array}{l}\text { 9. Open communication bridges the gap between patient's perception } \\
\text { of his situation and the reality }\end{array}$ & $\begin{array}{c}1 \\
(1.9 \%) \\
\end{array}$ & $\begin{array}{c}3 \\
(5.8 \%) \\
\end{array}$ & $\begin{array}{c}48 \\
(92.3 \%) \\
\end{array}$ \\
\hline $\begin{array}{l}\text { 10. Withholding negative information to a patient will result to a } \\
\text { better treatment outcome }\end{array}$ & $\begin{array}{c}38 \\
(73.1 \%)\end{array}$ & $\begin{array}{c}6 \\
(11.5 \%)\end{array}$ & $\begin{array}{c}8 \\
(15.4 \%)\end{array}$ \\
\hline $\begin{array}{l}\text { 11. An increasing need for more analgesic by a terminally-ill patient } \\
\text { reflects the progression of symptoms and underlying disease }\end{array}$ & $\begin{array}{c}12 \\
(23.1 \%)\end{array}$ & $\begin{array}{c}14 \\
(26.9 \%)\end{array}$ & $\begin{array}{c}26 \\
(50.0 \%)\end{array}$ \\
\hline $\begin{array}{l}\text { 12. It is the role of the physicians to address the psychosocial issues } \\
\text { of dying patients }\end{array}$ & $\begin{array}{c}3 \\
(5.8 \%) \\
\end{array}$ & $\begin{array}{c}5 \\
(9.6 \%) \\
\end{array}$ & $\begin{array}{c}44 \\
(84.6 \%) \\
\end{array}$ \\
\hline $\begin{array}{l}\text { 13. Higher doses of narcotics will shorten life or depress respiration } \\
\text { in dying patients }\end{array}$ & $\begin{array}{c}15 \\
(28.8 \%)\end{array}$ & $\begin{array}{c}16 \\
(30.8 \%)\end{array}$ & $\begin{array}{c}21 \\
(40.4 \%)\end{array}$ \\
\hline
\end{tabular}

2-C.Distribution of Respondents according to their Responses on the Different Skills Cases

\begin{tabular}{|l|c|c|c|}
\hline & \multicolumn{3}{|c|}{ RESPONSES } \\
\hline CASE 1 & DISAGREE & UNSURE & AGREE \\
\hline a. Write a Do-Not-Resuscitate order & $13(25.0 \%)$ & $6(11.5 \%)$ & $33(63.5 \%)$ \\
\hline b. Remove the patient from ventilator & $29(55.8 \%)$ & $8(15.4 \%)$ & $15(28.8 \%)$ \\
\hline c. Start morphine drip for the purpose of suppressing respiration & $42(80.8 \%)$ & $4(7.7 \%)$ & $6(11.5 \%)$ \\
\hline d. Stop total parenteral nutrition & $37(71.2 \%)$ & $8(15.4 \%)$ & $7(13.5 \%)$ \\
\hline e. Remove the patient out of the ICU & $20(38.5 \%)$ & $6(11.5 \%)$ & $26(50.0 \%)$ \\
\hline \multicolumn{4}{|l|}{} \\
\hline CASE 2 & DISAGREE & UNSURE & AGREE \\
\hline a. A psychologist or social worker should be called to help & $8(15.4 \%)$ & $3(5.8 \%)$ & $41(78.8 \%)$ \\
\hline b. The patient should be made comfortable and be allowed to die & $9(17.3 \%)$ & $12(23.1 \%)$ & $31(59.6 \%)$ \\
\hline c. The patient should be transferred to a long-term-care facility & $12(23.1 \%)$ & $8(15.4 \%)$ & $32(61.5 \%)$ \\
\hline \multicolumn{4}{|l|}{} \\
\hline CASE 3 & DISAGREE & UNSURE & AGREE \\
\hline $\begin{array}{l}\text { a. Include non- pharmacologic interventions and interdisciplinary } \\
\text { plan that include other healthcare professionals in addition to } \\
\text { pharmacologic treatment }\end{array}$ & $2(3.8 \%)$ & $4(7.7 \%)$ & $46(88.5 \%)$ \\
\hline $\begin{array}{l}\text { b. Refuse request to increase doses of pain medication because } \\
\text { she is showing signs of addiction }\end{array}$ & $24(46.2 \%)$ & $9(17.3 \%)$ & $19(36.5 \%)$ \\
\hline $\begin{array}{l}\text { c. Sit down and engage her in conversation encouraging her to } \\
\text { express her feelings }\end{array}$ & $2(3.8 \%)$ & $4(7.7 \%)$ & $46(88.5 \%)$ \\
\hline
\end{tabular}

\section{2-B. Distribution of Respondents According to their Responses on the Different Attitude Questions}

\begin{tabular}{|c|c|c|c|c|c|}
\hline & $\begin{array}{l}\text { STRONGLY } \\
\text { DISAGREE }\end{array}$ & $\begin{array}{l}\text { DIS- } \\
\text { AGREE }\end{array}$ & UNSURE & AGREE & $\begin{array}{l}\text { STRONGLY } \\
\text { AGREE }\end{array}$ \\
\hline $\begin{array}{l}\text { 1. Faith plays an important role in the ability of } \\
\text { patients to deal with medical illness and dying }\end{array}$ & 0 & $\begin{array}{c}4 \\
47.7 \%)\end{array}$ & $\begin{array}{c}4 \\
(7.7 \%)\end{array}$ & \begin{tabular}{|c|}
23 \\
$(44.2 \%)$
\end{tabular} & $\begin{array}{c}21 \\
(40.4 \%)\end{array}$ \\
\hline $\begin{array}{l}\text { 2. Physician- patient interactions would be } \\
\text { strengthened if physicians regularly discuss their } \\
\text { patient's spirituality or religion with them. }\end{array}$ & $\begin{array}{c}1 \\
(1.9 \%)\end{array}$ & $\begin{array}{c}8 \\
(15.4 \%)\end{array}$ & $\begin{array}{c}12 \\
(23.1 \%)\end{array}$ & \begin{tabular}{|c|}
20 \\
$(38.5 \%)$
\end{tabular} & $\begin{array}{c}11 \\
(21.2 \%)\end{array}$ \\
\hline $\begin{array}{l}\text { 3. Physicians should frequently initiate } \\
\text { discussions about spiritual /religious matters with } \\
\text { their patient during end of life care }\end{array}$ & $\begin{array}{c}3 \\
(5.8 \%)\end{array}$ & $\begin{array}{c}9 \\
(17.3 \%)\end{array}$ & $\begin{array}{c}17 \\
(32.7 \%)\end{array}$ & $\begin{array}{c}20 \\
(38.5 \%)\end{array}$ & $\begin{array}{c}3 \\
(5.8 \%)\end{array}$ \\
\hline $\begin{array}{l}\text { 4. Treating a dying patient is one of the most } \\
\text { unpleasant aspects of being a physician }\end{array}$ & $\begin{array}{c}3 \\
(5.8 \%)\end{array}$ & $\begin{array}{c}19 \\
(36.5 \%)\end{array}$ & $\begin{array}{c}4 \\
(7.7 \%)\end{array}$ & $\begin{array}{c}19 \\
(36.5 \%)\end{array}$ & $\begin{array}{c}7 \\
(13.5 \%)\end{array}$ \\
\hline $\begin{array}{l}\text { 5. If given a choice, I prefer to avoid contact with } \\
\text { dying people }\end{array}$ & $\begin{array}{c}4 \\
\\
(7.7 \%)\end{array}$ & $\begin{array}{c}20 \\
(38.5 \%)\end{array}$ & $\begin{array}{c}13 \\
(25.0 \%) \\
\end{array}$ & $\begin{array}{c}11 \\
(21.2 \%)\end{array}$ & $\begin{array}{c}4 \\
(7.7 \%) \\
\end{array}$ \\
\hline $\begin{array}{l}\text { 6. The physician should be comfortable providing } \\
\text { life- prolonging measures if the patient and } \\
\text { family request them }\end{array}$ & 0 & $\begin{array}{c}6 \\
(11.5 \%)\end{array}$ & $\begin{array}{c}6 \\
(11.5 \%)\end{array}$ & \begin{tabular}{|c|}
33 \\
$(63.5 \%)$
\end{tabular} & $\begin{array}{c}7 \\
(13.5 \%)\end{array}$ \\
\hline $\begin{array}{l}\text { 7. The physician should be comfortable } \\
\text { withdrawing life- prolonging measures if the } \\
\text { patient and family request them }\end{array}$ & $\begin{array}{c}3 \\
(5.8 \%)\end{array}$ & $\begin{array}{c}13 \\
(25.0 \%)\end{array}$ & $\begin{array}{c}10 \\
(19.2 \%)\end{array}$ & $\begin{array}{c}23 \\
(44.2 \%)\end{array}$ & $\begin{array}{c}3 \\
(5.8 \%)\end{array}$ \\
\hline $\begin{array}{l}\text { 8. Training and exposure in the care of the } \\
\text { terminally-ill should be mandatory to all } \\
\text { physicians }\end{array}$ & $\begin{array}{c}1 \\
(1.9 \%)\end{array}$ & $\begin{array}{c}5 \\
(9.6 \%)\end{array}$ & $\begin{array}{c}5 \\
(9.6 \%)\end{array}$ & \begin{tabular}{|c|}
28 \\
$(53.8 \%)$
\end{tabular} & $\begin{array}{c}13 \\
(25.0 \%)\end{array}$ \\
\hline $\begin{array}{l}\text { 9. It is more satisfying to work with patients who } \\
\text { are expected to improve than with patients who } \\
\text { are likely to die }\end{array}$ & $\begin{array}{c}3 \\
(5.8 \%)\end{array}$ & $\begin{array}{c}14 \\
(26.9 \%)\end{array}$ & $\begin{array}{c}2 \\
(3.8 \%)\end{array}$ & \begin{tabular}{|c|}
20 \\
$(38.5 \%)$
\end{tabular} & $\begin{array}{c}13 \\
(25.0 \%)\end{array}$ \\
\hline $\begin{array}{l}\text { 10. Caring for dying patients is rewarding or } \\
\text { fulfilling }\end{array}$ & $\begin{array}{c}2 \\
(3.8 \%)\end{array}$ & $\begin{array}{c}13 \\
(25.0 \%)\end{array}$ & $\begin{array}{c}12 \\
(23.1 \%)\end{array}$ & $\begin{array}{c}20 \\
(38.5 \%)\end{array}$ & $\begin{array}{c}5 \\
(9.6 \%)\end{array}$ \\
\hline
\end{tabular}

\section{APPENDIX 3 RELIABILITY ANALYSIS}

The frequency of responses for the 34 items of the questionnaire was tabulated, and none of the questions had $\geq 80 \%$ response in one category. All of the items, therefore, could discriminate between extreme responses using the frequency endorsement method.

Inter-item correlation matrix for each question variable should produce a matrix of positive correlations, ranging from modest values $(0.2-0.4)$ to moderate values $(0.4-0.6)$. One should consider excluding items with weak correlation $(<0.20)$ or negative correlations with most of the other items. However, items with good but negative correlations with the other items can be re-coded and maintained in the questionnaire.

For the first 13 items in the first domain (Part II: knowledge), 6 items had moderate inter-item correlation (q1 with q9, q4 with q5, q6 with q7 and $q 8$, $q 7$ with $q 8$ and $q 8$ with $q 9$ ) while some had modest inter- item correlation ( $q 1$ with $q 3, q 3$ with $q 7$ and $q 11, q 4$ with $q 7$ and $q 10, q 5$ with $q 9, q 10$ and $q 13, q 6$ with $q 9$, q7 with q9, q11and q12, q8 with q12 and $q 10$ with q13). Negative correlation was seen on $q 1$ with $q 2, q 4, q 6, q 11$; q2 with q6-9, q11-13; q3 with $q 4$ and q8; q4 with q11, q5 with q11, q6 with $q 10$ and $q 13$, $q 7$ with $q 10$ and $q 13 ; q 9$ with $q 11$ and $q 13 ; q 10$ with q11 and q12; q11 with q12, q12 with q13). 
For the second domain on attitudes (Part III), several items showed modest inter- item correlation, namely: $q 1$ with $q 6$ and q8, q3 with q8, q4 with q5 and q9; q5 with q10, and q8 with q10. Moderate inter- item correlation as seen with q2 with q3. Negative correlation was seen for some of the items.

For the third domain (Part IV: skills), a lot of the items had modest inter- item correlation: q1a with q1s, q1d and q2a; q1b with q2b, q1c with q3a and q3b; q1d with q1e and q2a; and q1e with q2b. Moderate inter- item correlation was seen on: q1a with $q 2 b, q 1 b$ with q1e and q2a; and q1e with q2a. Negative correlation was seen for many of the items.

Inter-total correlation. If an item belonged to a subscale and tapped into some aspect of the same underlying domain, then it should correlate with the subscale total omitting that item. One should consider excluding from the subscale any item with an item-total correlation of less than 0.2 .

Inter- total correlation for the first domain showed $r \geq 0.2$ for $q 3-q 9$. The rest, including $q 10, q 12$ and $q 13$ had $r<0.2$. Negative correlation was seen for items $q 1$ and $q 2$.

Inter- total correlation for the second domain showed $r \geq 0.2$ for $q 2$, q3, q8 and q10. The rest, including q1, q4, q5, q6, q7 and q9 had $r<0.2$. None of the items had negative correlation.

Inter- total correlation for the third domain showed $r \geq 0.2$ for q1a, q1b, q1d-e, q2a-b, q3a. Question q1c and q3c had negative correlation.

Cronbach's Alpha. The internal-consistency coefficient shows the similarity in measurement across items within the subscale. This is an index of inter-item consistency. The subscale should be homogenous and all items should be tapping different aspects of the same domain not the different parts of the different domains.

Cronbach's coefficient alpha for the first domain had values $>0.6$ for all combinations of not removing any or removing each question. Reliability coefficient of the 13 items is alpha 0.7 .

Cronbach's coefficient alpha for the second domain showed that the combination of all the questions and removal of each of the questions resulted to a scale reliability coefficients of $<0.6$, except for $q 10(0.6270)$. Values ranged from $0.3438-0.6270$. Reliability coefficient of the 10 items is alpha 0.501.

Cronbach's coefficient alpha for the third showed that the combination of all the questions and removal of each of the questions resulted to a scale reliability coefficients of 0.607 .

After reliability analysis, inter- total correlation for the three domains was $r \geq 0.2$ while combination of all the questions and removal of each of the questions resulted to a scale reliability coefficient of 0.7401 .

\section{ACKNOWLEDGEMENTS}

The authors are grateful to Amy M. Sullivan, Ed.D. of Dana- Faber Cancer Institute and Brigham and Women's Hospital, Harvard Medical School, Milagros F. Neri, MD.and Maria Dolores T. Teneza, MD of the Department of Community and Family Medicine of FEU- NRMF for their invaluable advice; and Ms. Ma. Grace C. Rosales for her assistance with the statistical analysis.

\section{REFERENCES}

1. Singer PA, Bowman KW. Quality end of life care: A global perspective. BMC Palliative Care. 2002 July 25. Available from: http://www.biomedcentral.com/1472-684X/1/4.

2. Bowman KW. Culture, ethics and biodiversity crisis of Central Africa. Advances in Applied Biodiversity 2001.2:167-174.

3. Von Gunten CF., Ferris FD., Emanuel LL. Ensuring competency in end of life care. JAMA. 2000 Dec 20; 284 (23): 3051-57.

4. McPhee SJ., Rabow MW., Pantilat SG., Markowitz AJ., Winker MA. Finding our way- Perspectives on care at the close of life. JAMA. 2000; 284:2512-2513.

5. Hill TP. Treating the dying patient: the dying for medical education. Arch Intern Med. 1995; 155: 1265-1269.

6. McCue JD. The naturalness of dying. JAMA 1995; 273: 1039- 1043.

7. Burge, F., Mclntyre P., Kaufman D., Cummings I., Frager G., Pollett A.: Family medicine residents' knowledge and attitudes about end-of-life care. J Palliat Care. 2000; 16: 5-12.

8. MacKinnon NJ, Molson JD, Douglas May J. Physician intervention in the dying process: a causal model of physician attitudes and the subjective likelihood of engaging in active euthanasia, physician- assisted suicide, and withholding treatment to terminally- ill patients. Electronic Journal of Sociology. 2003; 7. Available from: http//www.sociology.org/content/vol7.1/ mackinnon_etal.html.

9. Daaleman TP, VandeCreek L. Placing religion and spirituality in end of life care. JAMA. 2000 Nov 15; $284: 2514-2517$

10. Krings CL. Historical perspectives of hospice and palliative care including local and global socio-cultural factors. In: Post-graduate Course in Hospice and Palliative Care: New Trends and Directions; 1999 Nov 11-13; UP Manila, Philippines.

11. Teneza MD. Assessment of Knowledge, Attitudes and Practices in End of Life Care among FEUDr. Nicanor Reyes Medical Foundation Resident Physicians. In Press 2006.

12. Wu HY., Malik FA., Higginson IJ. End of life content in geriatric textbook: what is the current situation? BMC Palliative Care. 2006; 5:5. Available from: http://biomedcentral.com/1472$684 \mathrm{X} / 5 / 5$ 